\title{
Peculiarities in Understanding of Indirect Meaning of Proverbs and Idioms by Children of Pre-School Age*
}

\section{Особливості розуміння дітьми дошкільного віку переносного значення прислів'їв та ідіом**}

\author{
Larysa Kalmykova \\ Dr. in Psychology, Professor, \\ Head of the Department of \\ Psychology and Pedagogy of \\ Preschool Education
}

\author{
Лариса Калмикова \\ доктор психологічних наук, \\ професор, завідувач кафедри \\ психології і педагогіки \\ дошкільної освіти
}

\author{
E-mail: klo377@ukr.net \\ orcid.org/0000-0002-7538-2635
}

\author{
Наталія Харченко \\ кандидат педагогічних наук, \\ доцент
}

E-mail: $\underline{\text { harchenko123@rambler.ru }}$
orcid.org/0000-0002-9958-5226
Researcher ID: F-9093-2018

* This study is done within the framework of L.O. Kalmykova's scientific school «The Dynamics of problematic forming of Ukrainian psycholinguistics in the context of development of Ukrainian and world science», confirmed by the Scientific Board of Pereiaslav-Khmelnytskyi Hryhorii Skovoroda State Pedagogical University (Minutes № 9 from the 19th. July 2017) and within the framework of the State project and finance support of the Ministry of Education and Science of Ukraine (Registration number 14/17-19).

** Дослідження виконане в межах наукової школи проф. Л.О. Калмикової «Динаміка становлення проблематики української психолінгвістики в контексті розвитку вітчизняної та світової науки», затвердженої Вченою Радою ДВН3 «Переяслав-Хмельницький державний педагогічний університет імені Григорія Сковороди» (протокол № 9 від 19.06.2017р.) та в рамках Держбюджетного проекту за фінансової підтримки Міністерства освіти і науки України (Реєстраційний номер 14/17-19). 
Inna Mysan

Ph.D. in Pedagogy,

Assistant Professor
Інна Мисан

кандидат педагогічних наук, доцент

E-mail: mysan.iv79@gmail.com

orcid.org/0000-0001-9416-4484

\author{
Pereiaslav-Khmelnytskyi \\ Hryhorii Skovoroda State \\ Pedagogical University \\ $\triangle$ 30, Sukhomlynskyi Str., \\ Pereiaslav-Khmelnytskyi, Kyiv Reg., \\ Ukraine, 08401
}

\author{
ДВНЗ «Переяслав-Хмельнищький \\ державний педагогічний \\ університет імені Григорія \\ Сковороди» \\ вул. Сухомлинського, 30, \\ м. Переяслав-Хмельницький, \\ Київська обл., Україна, 08401
}

Original manuscript received December 16, 2017

Revised manuscript accepted September 17, 2018

\begin{abstract}
The study reveales psycholinguistic peculiarities of understanding of indirect meaning of the proverbs and idioms of Ukrainian speaking pre-school children. The experiment took place on the basis of pre-school education establishments of Ukraine. The participation number is 378 children at the age of 5 years (till 5.5 years).

The used psycholinguistic methods are: a) "evaluation of understanding of the indirect metaphors meaning" (Vygotskyi, 2000); b) "evaluation of proverbs understanding" (Luriia, 1998). The other used psycholinguistic methods are: a) "Proverbs understanding" (Luriia, 1998), adopted for the diagnoses of metaphoric understanding of idioms meaning by children; b) "The interpretation choice of one of the given variants of meanings" (Baskakova \& Glukhov, 2008; Eliseeva, Gutsc \& Marini, 2017); c) selection of one of several possible paraphrases (Winner, Rosenstiel \& Gardner, 1976; Vosniadou \& Ortony, 1983). Children were proposed to express themselves in order to find out how they understand given proverbs and idioms. If they had difficulties in meaning explication, so they were proposed some variants of proverbs and idioms interpretations, among which the first was correct (with indirect meaning) and the second with the direct meaning and the third with occasional associative meaning.

The experiment proved such results: there are children with obvious intuitive language ability to feel the general meaning of proverbs and idioms. The part of children of the age of five years is able to verbalize the indirect proverb meaning $(4,2 \%)$ and idioms meaning $(7,4 \%)$. In the situation with one variant of meaning among some paraphrases $16,4 \%$ of children chose the
\end{abstract}


correct proverb meaning, 20,4\% of children chose the correct idiom meaning. More difficult for children's understanding are proverbs, than idioms. It could be explained in the way, that idiomatic expressions are one whole and one nomination that a child often interprets in daily life from adults in some specific life situations. That is why he or she uses more quickly the heard word complex in a new association chain, abstracting from the direct meaning of idiomatic words. The proverb understanding is seen by child as more complex cognitive task, which foresees decipherment of the common thought or conclusion, understanding its meaning (implication). That is why the proverbs cause more problems among children than idioms.

Key words: indirect meaning of words, proverbs, idioms, perception, understanding, children of pre-school age.

\section{Вступ}

Проблема розуміння дітьми переносного значення слів завжди була предметом уваги представників психолінгвістики розвитку, оскільки iï вирішення відкриває один із шляхів до розкриття загадковості такого складного феномену, як мовна компетенція, яка виформовується в дитини переважно на дошкільному етапі мовленнєво-мовного онтогенезу та пов'язана з розвитком вербальнологічного мислення й внутрішнього мовлення. Особливості розуміння дітьми вторинного (переносного) значення слова, що виникає на основі різних видів асоціативних зв'язків засобом метонімії, метафори та інших перенесень, вивчалися вченими на матеріалі різних національних мов.

Аналіз розвідок, присвячених розумінню ідіом та прислів'їв, засвідчив, що означена проблема є предметом уваги вчених різних країн світу. Досліджується розуміння цих висловів у дорослих i дітей на різних етапах їх мовленнєво-мисленнєвого онтогенезу. Особливий інтерес у науковців викликає питання розуміння метафоричних висловів саме в дітей віком від 4 до 11 років. I це не випадково, адже результати емпіричного дослідження великою мірою спроможні пояснити, на думку С. Хсейх і Дж. Хсю (Hsieh \& Hsu, 2010), функціонування мови й комунікативних ситуацій. Проте, як свідчать результати аналізу наукової та навчально-методичної літератури, розвідок, присвячених дослідженню розумінню дітьми ідіом значно більше, ніж тих, що орієнтовані на 3'ясування змісту прислів 'їв. 
Розуміння дітьми дошкільного віку метафоричного значення ідіом досліджували східноєвропейські вчені (Артемьева \& Нуриева, 2007; Береснева, 1995; Гвоздев, 1961; Детинина, 1987; Дьяченко, 1996; Эльконин, 1964; Елисеева \& Горобец, 2017; Люблинская, 1971; Мисан, 2018; Митькина, 2001; Мирошниченко, 1986; Синиця, 1974; Чуковский, 1960; Харченко, 1987 та ін.). У західноєвропейській та американській психолінгвістиці це питання вивчалося на матеріалі різних національних мов багатьма вченими (Caillies \& Le Sourn-Bissaoui, 2006, 2013; Cacciari \& Levorato, 1989; Hsieh \& Hsu, 2010; Levorato \& Cacciari, 1992; Le Sourn-Bissaoui, Caillies, Bernard et al., 2012; Chiappe, \& Chiappe, 2007; Honeck, Sowry \& Voegtle, 1978; Ackerman, 1982, 1983; Gibbs, 1987; Lodge \& Leach, 1975; Prinz, 1983; Eliseeva, Gutsc \& Marini, 2017; Ezell \& Goldstein, 1991; Vosniadou \& Ortony, 1983, 1986; Nippold, Leonard \& Kail, 1984; Pearson, 1990; Rubio-Fernández \& Grassmann, 2016; Winner, Rosenstiel \& Gardner, 1976) та ін.

Щодо розуміння значення прислів'їв, то дослідження цієї здатності здійснювалося переважно на матеріалі обстеження цісї компетенції в дорослих або юних респондентів (Ильенков, 1968; Рубинштейн, 2001; Honeck, Sowry \& Voegtle, 1978; Yoon, Schwarz \& Nippold, 2016; Nippold, Moran \& Schwarz, 2001; Nippold, Allen \& Kirsch, 2000; Gibbs, 1995; Kemper, 1981; Uekermann, Thoma \& Daum, 2008 та ін.). Студіювання здатності дітей розуміти образне значення прислів”ів представлене значно меншою кількістю досліджень (Выготский, 2000; Люблинская, 1971; Honeck, Sowry \& Voegtle, 1978 та ін.).

Аналіз наукових джерел засвідчив, що при всій здавалося б грунтовній дослідженості й багатомовній представленості питання розуміння дітьми дошкільного віку ідіом і прислів'їв у періодичних виданнях різних країн світу, ця проблематика не знайшла достатнього вивчення стосовно україномовних дітей 5-6-річного віку, які готуються до вступу в 1-й клас школи. Тому метою статті $€$ висвітлення результатів теоретичного й експериментального досліджень, а саме: по-перше, стану вивченості розуміння переносного значення прислів'їв та ідіом у вітчизняній і зарубіжній психолінгвістичній літературі; по-друге, типових особливостей та індивідуальних відмінностей у розумінні україномовними дітьми старшого дошкільного віку переносного значення саме цих 
Peculiarities in Understanding of Indirect Meaning of Proverbs...

своєрідних зворотів - стійких нерозчленовуваних за змістом, який $\epsilon$ інтегрованим і слова-компоненти якого, втрачаючи буквальну семантику, в метафоричній формі виражають узагальнену думку.

\section{Методи й методики дослідження}

У процесі вивчення стану розвиненості й особливостей розуміння дітьми 5-ти років переносного значення прислів 'їв та ідіом використовувалися теоретичні й емпіричні методи. Із сукупності теоретичних методів вибрано такі: 1) аналіз вітчизняних i зарубіжних психолінгвістичних джерел для встановлення повноти дослідженості окресленої в заголовку статті проблеми та виокремлення теоретичних положень за визначеною темою; 2) систематизація даних теоретичного аналізу для отримання цілісного уявлення про стан розробленості питання, що вивчається, та виділення основних підходів і принципів дослідницької роботи; 3) узагальнення отриманих у результаті аналізу наукових тез 3 метою уточнення дефініцій наукових понять, на яких грунтується студіювання дитячого сприймання й розуміння; 4) квалітативний аналіз для здійснення логічного підсумку, зробленого на основі спостережень, опитування та розгляду експериментальних психолінгвістичних фактів щодо перебігу процесу аудіювання в дітей; 5) квантифікація - для встановлення істинності чи хибності дитячих міркувань при поясненні дітьми значення ідіом та прислів”ї; 6) висновування для виведення з результатів дослідження тверджень щодо розвиненості розуміння дітьми переносного значення. Серед емпіричних методів вибрано перш за все такі, що $є$ безпосередньо психолінгвістичними методами, зокрема метод оцінки розуміння смислу переносного значення метафор (Выготский, 2000), метод оцінки розуміння смислу прислів’їв (Лурия, 1998), метод прямого тлумачення слова (Выготский, 2000), метод парафраз (Winner, Rosenstiel \& Gardner, 1976); метод вибору одного варіанта значення із кількох парафраз («metod of select one of several possible paraphrases») (Winner, Rosenstiel \& Gardner, 1976; Vosniadou \& Ortony, 1983; Eliseeva, Gutsc \& Marini 2017). Крім того, опосередковано слугували для встановлення психолінгвістичного діагнозу стану розвиненості й особливостей розуміння дітьми дошкільного віку переносного значення ідіом і прислів”ів такі методи, як: опитування дітей, фіксація їхніх висловлювань на диктофоні, бесіди 3 дітьми - 
для отримання емпіричних даних; констатувальний експеримент для здійснення процедури опитування й фіксації стану розвитку та отримання якісних характеристик щодо розуміння визначених типів фразем; квантитативний метод - для отримання кількісних показників, квантифікаційний метод - для кількісного вираження якісних ознак розуміння переносного значення.

Для перевірки гіпотези застосовувалася психолінгвістична методика «Розуміння прислів”їв» (Лурия, 1998), яка дозволяла отримувати дані про стан розвиненості в дітей 5-річного віку здатності декодувати смисл (підтекст) прислів”ї. Вибір цієї методики був зумовлений тим, що саме в прислів'ях яскраво проявляється конфлікт між системою значень, виражених граматичною конструкцією, i внутрішнім підтекстом, смислом. Для релевантного розуміння прислів”їв дошкільникам необхідно абстрагуватися від безпосередньої системи значень i виявити внутрішній смисл, втілений у системі розгорнутих зовнішніх значень відповідного стійкого крилатого виразу. Процедура проведення експерименту: дошкільникам було запропоновано прослухати 10 прислів'їв і пояснити, як вони розуміють той чи той вираз. Фактичний матеріал для аналізу: «Ласа кішка до риби, та у воду лізти не хоче», «Моя хата з краю: нічого не знаю», «Що посієш, те й пожнеш», «Хочеш їсти калачі - не сиди на печі», «Шила в мішку не сховаєш», «Не плюй у криницю, бо згодиться води напитися», «Не все те золото, що блищить», «Слово - не горобець, вилетить не піймаєш», «Відвага мед п’є», «Знає кішка, чиє м’ясо з’ї̈ла». Співбесіда проводилася 3 кожною дитиною індивідуально, щоб інші діти не чули пояснень однолітків. Завдання пояснити значення прилів'ї і застосування їх у житті діти виконували протягом десяти днів - одне прислів’я в день). Для зацікавлення й активізації уваги використовувалися ігрові методи: поясни Незнайкові, як ти розумієш цей вираз, бо він не може зрозуміти його. Інтерпретування дітей фіксувалися на диктофон і в автентичній формі переносилися в протоколи обстеження. К. Ушинський зауважував, що в кожному прислів’”, не дивлячись на його лаконічність, є те, що необхідно дитині зрозуміти, бо «кожне прислів'я - це маленька розумова задача, абсолютно посильна дитині» (Ушинский, 1949, т. 6: 299).

Якщо діти не могли пояснити їх зміст, то використовувався інший варіант методу «оцінки розуміння смислу прислів ऑ̈в» - «вибір 
Peculiarities in Understanding of Indirect Meaning of Proverbs...

одного тлумачення із поданих варіантів значень» (Баскакова \& Глухов, 2008; Eliseeva, Gutsc \& Marini, 2017), метод вибору одного варіанту значення із запропонованих кількох парафраз / «Metod of select one of several possible paraphrases» (Winner, Rosenstiel \& Gardner, 1976; Vosniadou \& Ortony, 1983). Він передбачав надання до запропонованих прислів”їв кількох варіантів інтерпретацій їх у вигляді двох-трьох готових відповідей-пояснень значення прислів'їв, серед яких - перша була правильною відповіддю (смисл прислів'я); друга - в прямому значенні; третя - 3 випадковими асоціативним значенням, наприклад, до прислів'я «Хочеш їсти калачі - не сиди на nечi» - правильним є такий зміст: 1. «Щоб щось у житті мати, щоб досягти успіху, треба багато працювати, не лінуватися» (синонім: «Без труда нема плода»). 2. «Якщо хтось хоче поїсти, то на печі не сидить, а за столом. 3. На печі тепло сидіти, а калачі дуже смачні. У такий спосіб з'ясовувалося, по-перше, чи має дитина труднощі в розумінні переносного значення прислів'я, чи, навпаки, розуміє його, але при цьому затрудняється лише у вербалізації того, що нею розуміється; по-друге, чи здатна вона вибирати 3 поданих їй кількох зразків варіант саме 3 переносним - абстрактним значенням, а не 3 денотативним чи асоціативним значенням. Якщо в дитини немає чіткого розуміння узагальненого смислу прислів'я, вона буде мислити конкретно, найчастіше вибиратиме 3 поданих їй зразків будь-яке неістотне пояснення, пов'язуючи його 3 конкретними образами.

Оцінювалася якість тлумачення прислів'їв при акцентуванні уваги на тому, чи орієнтуються діти на переносний смисл, який потребує абстрагування уяви від конкретного значення прислів'я, а чи судження дітей мають конкретне спрямування думки, що випливає із прямого змісту слів, які $є$ складовими компонентами прислів'я. Методика «Розуміння прислів'їв» була адаптована й для діагностування розуміння дітьми метафоричного значення ідіом, зокрема таких, як: розв'язати язик, кривити душею, знати на зубок, язик без кісток, водою не розлити, ловити гав, лічити ворон, бити байдики, дати спокій. Дітям пропонувалися завдання на інтерпретацію цих логіко-смислових метафоричних виразів. Використовувався метод «оцінки розуміння переносного смислу метафор» (Выготский, 2000). Як і в попередній методиці використовувався метод вибору з поданих дітям готових пояснень 
до метафоричних виразів. При використанні цього методу робився висновок не тільки про спроможність дітей розуміти смисл ідіом, а й про рівні розвитку цього розуміння, які засвідчували про індивідуальні стани функціонування цієї мовленнєвомовної компетенції у різних дітей. Важливо зазначити, що для констатувального експерименту були відібрані ідіоми, які в роботі вихователя 3 дітьми не використовувалися. Тобто, до проведення емпіричного дослідження дошкільники не чули їх ні в повсякденному житті (режимних процесах), ні в контексті літературних творів.

\section{Результати теоретичного дослідження}

Згідно з завданнями теоретичної частини цього дослідження був проведений аналіз аналогічних за проблематикою наукових розвідок, які здійснювалися як в Україні, так і за кордоном. Серед презентованих досліджень щодо розуміння значення ідіом особливо виокремлюємо ті, що стосуються саме дітей дошкільного віку. Отже, було отримано такі узагальнені результати. Встановлено, що в Україні питання освоєння дітьми переносного значення прислів'їв та ідіом висвітлено в небагатьох працях (Синиця, 1974; Калмикова, Мисан, 2014; Мисан, 2015, 2017, 2018). Так, І. Синиця здійснив дослідження фразем на матеріалі української мови. Учений аналізував як питання аудіювання фразеологізмів (хоча цей термін він не використовує), так і функціонування їх в усному й писемному мовленні дітей у зв'язку з розвитком довготривалої та оперативної пам'яті. Розуміння переносного значення фразеологізмів, на думку психолога, - це початок їх засвоєння.

Оволодіння дошкільниками ідіоматичним значенням зумовлене, як зазначають Л.О. Калмикова і І.В. Мисан (2014), початком розуміння ними домінуючого в ньому конотативного або експресивно-емоційного аспекту; смисловим і системним розвитком слів; опануванням метафоризації вільного словокомплексу (переінтеграції сем), цілісної семантики ідіоматичних одиниць. Розуміння значення фразеологізмів пов'язується із здійсненням у дитини смислового й системного розвитку слів, засвоєнням дошкільником денотативного та конотативного значень; поступовим оволодінням ідіоматичним значенням. 
Peculiarities in Understanding of Indirect Meaning of Proverbs...

I. Мисан $(2017,2018)$ встановлено, що ступінь проникнення в переносне значення ідіом залежить у дітей від багатьох чинників, зокрема: а) розуміння прямого значення кожного окремого слова, що в нього входить; б) близькості життєвого досвіду, зафіксованого в прямому значенні, до досвіду дітей; в) рівня розвитку абстрактного мислення й мовлення; г) загального когнітивного та емоційновольового розвитку. Культурно-змістовий обсяг представленого в ідіомах концепту, що освоюється дітьми, виявляється ширшим, ніж лаконічна словникова дефініція, якою вони володіють. Правильний відбір ідіоматичного значення при презентації їм варіантів значень засвідчує як розуміння дітьми змісту ідіом, так і значну роль чуття мови в сприйманні та осмисленні їх значення. Розуміння переносного значення ідіом на узагальненому (абстрактному) рівні, не виявлено. Характерну для дітей конкретизацію при інтерпретуванні ідіом дослідниця пояснює, з одного боку, початком вникання їх у переносне значення ідіом, а 3 іншого - недостатнім життєвим досвідом, який заважає їм піднятися (без відповідного навчання) на вищі сходинки узагальнення ідіоматичних виразів.

Проблема розуміння дітьми переносного значення слів та ідіом була й залишається до цього часу предметом дослідження в зарубіжній психолінгвістиці. Одразу зазначимо, що в слов'янських та інших національних мовах є розбіжності в термінології. Зокрема, в українській мові функціонують терміни «фразеологізми», «ідіоми». В інших мовах використовується тільки термін «ідіоми» для позначення різних метафоричних і метонімічних образних висловів, а $з$ метою їх диференціації вживаються словосполучення «подільні ідіоми» й «неподільні ідіоми». Подільні ідіоми розглядаються як подільні за рівнем семантичної злитності складових компонентів, тобто їх структура здатна розпадатися на семантико-смислові компоненти. Ідіоматичне значення таких фразеологічних одиниць більшою мірою $\epsilon$ сумою прямих значень утворюючих його компонентів. «У неподільних ідіомах пряме значення окремих слів, що утворюють фразеологічні одиниці, ніяким чином не сприяють виведенню ідіоматичного значення фразеологічної одиниці в цілому» (Елисеева \& Горобец, 2017: 18).

У зарубіжних наукових розвідках висвітлено особливості розуміння прислів'їв та ідіом у дітей, які говорять різними мовами, зокрема: італійською (Cacciari \& Levorato, 1989; Levorato \& 
Cacciari, 1992), франиузькою (Callies \& Le Sourn-Bissaoui, 2006, 2013; Le Sourn-Bissaoui, Caillies, Bernard et al., 2012), англійською (Lodge \& Leach, 1975; Vosniadou \& Ortony, 1983; Nippold, Leonard \& Kail, 1984; Gibbs, 1987; Winner, 1988; Ezell \& Goldstein, 1991), норвезькою (Rubio-Fernández \& Grassmann, 2016), китайською (Hsieh \& Hsu, 2010), російською (Eliseeva, Gutsc \& Marini, 2017; Елисеева \& Горобец, 2017). Ученими встановлено, що:

- діти дошкільного віку здатні зрозуміти образне значення ідіом, представлених у контексті (Caillies \& Le Sourn-Bissaoui, 2006);

- розуміння 5-річними дітьми подільних ідіом зумовлене розмовними перспективними оцінками й мовними навичками, тоді як засвоєння неподільних ідіом пов'язане виключно з мовними навичками (Le Sourn-Bissaoui, Caillies, Bernard et al., 2012);

- дошкільники краще розуміють ідіоми (які є застиглими, стійкими словосполученнями), ніж фразеологізми, представлені різноманітністю синтаксичних форм; з урахуванням контексту діти цього віку краще пояснюють образні ідіоми, прямі (буквальні) й ідіоматичні, інтерпретації яких тісно пов'язані, ніж вони тлумачать ідіоми, денотативне й переносне значення яких не були пов'язаними (Gibbs, 1987);

- діти здатні здійснювати семантичний аналіз, щоб зрозуміти фразеологічне значення прозорих ідіом, відчувають смисл у контексті; вони опрацьовують мову як на рівні фрази, так i на рівні дискурсу, встановлюючи образний смисл (Cain, Towse \& Knight, 2009);

- навіть наймолодші діти (3-4-5-річні) спроможні розмежовувати літературні, метафоричні й штучні (аномальні) порівняння, розуміють, що терміни 3 метафоричних порівнянь, на відміну від літературних, відносяться до різних умовних категорій; до 4-х років у дітей є певна елементарна (рудиментарна) метафорична компетентність (Vosniadou \& Ortony, 1983);

- за певних умов навіть діти дошкільного віку демонструють розуміння метафоричних виразів (Vosniadou, Ortony, Reynolds \& Wilson, 1984). Автори прогнозують, що діти можуть i роблять висновки 3 інформації, представленої в лінгвістичному й ситуаційному контексті, в якому виражена метафора - висновки, які допомагають дітям зрозуміти передбачуваний смисл метафори (Vosniadou, Ortony, Reynolds \& Wilson, 1984). 
Peculiarities in Understanding of Indirect Meaning of Proverbs...

- для дітей 3-5 років метафори не $є$ семантично аномальними (безсмисловими, несмисловими); вони (незалежно від віку й статі) опрацьовуються дітьми на рівні з буквальною мовою метафоричних висловів; метафора рано з'являється в лінгвістичному вживанні дитини; образна мова, зауважують автори, має посісти більш провідне значення в лінгвістичній теорії, ніж це було представлене раніше (Pearson, 1990). Ці висновки аргументуються тим, що імітація (дослідження будувалося на завданнях повторення метафор, нормативних і семантично аномальних речень) передбачає парафраз (переказ змісту твору або чужих думок своїми словами), який викликає в маленьких дітей труднощі; завдання на парафраз розповідей, які закінчуються метафоричним реченням, на думку науковців, недооцінюють можливості маленької дитини розуміти метафори. Діти, які інтерпретували метафоричні речення за допомогою іграшок, виставляючи їх у реальному часі й світі, розуміли зміст ідіом краще, ніж діти, які виконували це завдання через парафраз (Vosniadou \& Ortony, 1986);

- 6-річні дошкільники та діти різних вікових категорій (від 6 до 14 років) інколи інтерпретували метафори як опис магічних ситуацій при виконанні 2-х завдань для оцінки їхньої здатності або пояснювати метафоричні речення, або вибирати один 3 4-х можливих парафраз. Шестирічкам були притаманні метонімічні й примітивно метафоричні інтерпретації. Результати цього дослідження засвідчують наявність у дітей певних когнітивних передумов зрілого метафоричного розуміння (Winner, Rosenstiel \& Gardner, 1976).

У дослідженні (Caillies \& Le Sourn-Bissaoui, 2013) доводиться, що розуміння 6-річними дітьми неподільної ідіоми пояснюється навичками, що представлені в теорії інтелекту.

Наукова розвідка (Cacciari \& Levorato, 1989) засвідчила, що коли ідіоми представлені в багатому інформаційному середовищі, діти спроможні зрозуміти їх образний смисл у віці 7-ми років, а також, що вони меншою мірою здатні вживати ідіоми, ніж розуміти ïx; діти здатні сприймати, що мова може бути як образною, так і буквальною. Напротивагу цій гіпотезі в подальших своїх розвідках (Levorato \& Cacciari, 1992) ці вчені сформулювали іншу частково альтернативну гіпотезу - про експонування, згідно з якою результати дослідження засвідчили, що частота впливу ідіом на 
дітей відіграє другорядну роль і тільки для дітей, які ще нездатні використовувати контекстну інформацію. Авторами запропонована модель набуття здатності осмислювати образні значення - «model is proposed in order to account for figurative competence acquisition» (там само: 415).

Дослідження P. Prinz (1983) присвячувалося проблемі розвитку розуміння дітьми ідіоматичного виразу. Ученим встановлено, що в процесі розуміння ідіом діти використовують стратегію лібералізації (у віці від 6 до 9-ти років) і стратегію ідіоматичного смислу. Ці стратегії, зауважує вчений, розвиваються в дітей до появи здатності усно інтерпретувати ідіоми.

Розуміння прислів'їв вивчалося в розвідці R. Honeck, B. Sowry \& K. Voegtle (1978). За умовами проведення діагностування діти порівнювали кожне прислів'я з двома тематичними картинками, які не тільки допомогли зменшити навантаження на виконання завдання 3 розуміння прислів'я, а й слугували контекстуальною основою для утворення загального образного значення як зображуваного, так і власне змісту прислів'я.

Н. Єлісеєва і О. Горобець експериментально встановили можливість російськомовних дітей-монолінгвів коректно визначати ідіоматичне значення одиниць вже в дошкільному віці. Дослідницями було відмічено, що в цьому віці діти схильні розбивати ідіоми на окремі частини (слова) та інтерпретувати тільки їх пряме значення. До 7 років діти коректно визначали тільки ідіоматичне значення в 40\% випадках, у той час у $30 \%$ випадках дошкільники давали неправильні відповіді, схиляючись до варіанту, що відображає пряме значення виразу. Починаючи з 7-8-річного віку здатність дітей коректно інтерпретувати зміст ідіом значно прогресує (Елисеева \& Горобец, 2017).

У дослідженні Т.В. Артем'євої і А.С. Нурієвої (2007) було передбачено, що робота над прислів'ями буде сприяти розвиткові словесно-логічного мислення дошкільників, узагальненню й проникненню в їх смисли. Високий рівень розвитку здатності виокремлювати істотні ознаки предметів і встановлювати логічні зв'язки й відношення між предметами i явищами не виявлено. Більшість дітей перебували на середньому й нижчому за середній рівнях розуміння смислу прислів 'їв. 
Peculiarities in Understanding of Indirect Meaning of Proverbs...

У процесі теоретичного дослідження також було виділено наукові положення, які стали теоретико-методологічною основою емпіричної частини цієї розвідки. Їх суть полягає в наступному:

- уміння свідомо оперувати словами 3 перемінними значеннями засвідчує наявність такої узагальненої думки, яка здатна співвідносити загальне й часткове в їх єдності (Рубинштейн, 2001: 362);

- виникла можливість злиття предметного змісту образу одного предмета 3 предметним змістом образу другого об'єкта, яке зумовлене процесуальністю уяви, спричиняє розвиток метафоричності мовлення (Эльконин, 1964);

- труднощі розуміння переносного значення прислів'я полягає в гальмуванні прямих образів або асоціацій, які воно породжує, та в переході до його внутрішнього значення й підтексту. Загальний смисл, що міститься в ідіомі, прислів'ї, не випливає безпосередньо прямо ні 3 їх конкретних слів, ні з сполучуваності цих слів. Переносний смисл потребує абстрагування від конкретного прислів'я чи ідіоми та широкого узагальнення (Artemyeva, 2013);

- перенесення здійснюється «за законом комплексного мислення» (Выготский, 1999: 116).

У основу емпіричного дослідження покладено, по-перше, розуміння пов'язаних з переносним значенням категорій; по-друге, здійснене шляхом узагальнення уточнення формулювань окремих понять; по-третє, визначення нових понять.

Переносне значення розглядаємо як таке, що сформувалося в процесі вживання слова в мові; воно не випливає з основного змісту слова (Літературна енциклопедія, 2007). Це неосновне, вторинне значення, набуте словом, яке функціонує одночасно 3 прямим значенням, але в різних стилях. Воно виникло на основі різних видів асоціативних зв'язків і пов'язане з основним, провідним значенням, відношеннями метонімічної, метафоричної залежності або певними асоціативними ознаками (Словник лінгвістичних термінів, 1985; Большой энциклопедический словарь, 2004). Зазначимо, що метафора й «метафоричність» у науці вживаються в ширшому значенні (назва будь-якого переосмислення) i вужчому (на означення певного виду перенесення). За К. Бюлером, це намагання визначити невідоме через відоме. За Г. Паулем, - використати живі та найяскравіші уявлення. Метафоризація грунтується на 
використанні знаків однієї концептосфери на позначення іншої, $є$ образно-семантичним чинником фразеутворення і фразеволодіння в дітей. Переносне значення - узагальнено цілісне значення, місткіше й багатше порівняно зі значенням лексем і полягає в домінанті його конотативного, або експресивно-емоційного аспекту. Конотащії $є$ частинами семантичних структур мовних одиниць; додатковими семантичними й прагматичними особливостями («співзначеннями») ідіоматичного значення, які нашаровуються на їх предметнопонятійний аспект і зумовлюється як змістом, так і внутрішньою формою фразеологізму (Ужченко \& Ужченко, 2007).

Переносне значення можна потрактувати i як алегоричне значення, тобто утворене на алегорії: втілення абстрактного поняття в конкретному художньому образі; алегорію розглядаємо як вислів, що виражає абстрактне поняття через конкретний художній образ; зображення, що грунтується на приховуванні реальних осіб, явищ i предметів під конкретними художніми образами 3 відповідними асоціаціями 3 характерними ознаками приховуваного. Переносне значення: а) міститься в образному вислові, що виражає абстрактне поняття через конкретний художній образ; б) не спроможне передати або відтворити буквальний зміст ідіоматичного виразу або прислів'я; в) конкретніше i вужче за лексичне, оскільки більшість ідіом і народних афоризмів і паремій - однозначні; г) утворюється в результаті переходу слова від позначення одного предмета до номінації іншого. Саме тому воно протиставляється вихідному денотативному значенню (Літературознавчий словникдовідник, 2007).

Оволодіння переносним значенням експлікуємо як процес набуття дитиною вторинного, похідного значення слова в результаті свідомого сприймання, розуміння та вживання його в мовленні для позначення предмета або явища, які не $є$ його звичайним або природним референтом.

У контексті нашого дослідження iдioмy розглядаємо як самобутній стійкий, властивий лише живій мові вираз, що незалежно від значення слів у ньому передає єдине поняття (Сучасний словник іншомовних слів, 2008); своєрідний неподільний фразеологічний зворот, який за будовою $є$ нерозчленованим словосполученням; в ідіомі виявляється національний колорит, який втрачається при перекладі на іншу мову (Там само: 293). 
Peculiarities in Understanding of Indirect Meaning of Proverbs...

Розуміння значення ідіоми визначаємо як здатність дитини осмислювати фразеологізми не в прямому значенні, а в о́бразній номінації; ㄲï спроможність абстрагувати вжите в переносному значенні словосполучення, відокремити від словосполучення, вжитого в прямому значенні шляхом роз'єднання міцно усталеного зв'язку і включення його в новий ланцюг асоціацій.

Прислів'я розглядаємо як жанр фольклору, малу форму поетичної творчості, народний афоризм, образний, лаконічний, афористично стислий, граматично й логічно завершальний та ритмізований за формою вислів, що містить узагальнену думку, висновок, інакомовність з напутнім смислом. Афоризм - короткий влучний оригінальний вислів, що виражає узагальнену думку в легкій для розуміння й сприймання, виразній для запам'ятовування формі, яка згодом неодноразово відтворюється іншими людьми (Літературознавчий словник-довідник, 2007).

Розуміння значення прислів 'ів вербалізуємо як здатність дитини вникати в повчальний смисл афористичного, образного вислову, здійснюючи своєрідний шлях від зовнішньої форми й конкретних особливостей до його внутрішнього значення й підтексту; це спроможність абстрагуватися від конкретного, що прямо витікає з їх змісту, думки й зосередитися на узагальненому понятті, що потребує абстрагування від конкретного значення та розуміння нового.

Було висловлено припущення, згідно з яким тлумачення дітьми переносного значення прислів'їв та ідіом уможливлює, по-перше, встановлення факту, розуміє чи не розуміє їх та чи інша дитина; подруге, з'ясування того, як саме дитина розуміє прислів'я та ідіоми і які специфічні особливості й рівні цього розуміння; по-третє, пояснення того, як розвиваються й функціонують фігуративна й афористично-образна компетенції.

\section{Результати емпіричного дослідження}

Аналіз результатів виконаних дітьми завдань за методикою «Розуміння прислів '̈в» (О.Р. Лурія), присвяченої вивченню стану та рівнів розвиненості в дітей старшого дошкільного віку здатності дітей 5-річного віку розуміти глибинний смисл (підтекст) прислів'їв, засвідчив наступне: у 4,2\% дітей 5-річного віку розвинена елементарна метафорична компетенція (вони пояснювали переносне значення афористичних виразів); 35,2\% дітей пояснювали зміст 
прислів'їв у прямому значенні; 57,4\% дітей тлумачили зміст прислів 'їв через асоціативні значення; ніхто 3 дітей не давав семантично аномальних тлумачень змісту прислів'їв; 3,2\% дітей не вступали в комунікацію з експериментатором (див. табл. 1).

Таблиця 1. Стан розвитку в дітей здатності розуміти пряме значення та глибинний смисл прислів'їв

\begin{tabular}{cccccc}
\hline $\begin{array}{c}\text { Кіл-сть } \\
\text { дітей }\end{array}$ & $\begin{array}{c}\text { Пояснюють } \\
\text { переносне } \\
\text { значення }\end{array}$ & $\begin{array}{c}\text { Пояснюють } \\
\text { пряме } \\
\text { значення }\end{array}$ & $\begin{array}{c}\text { Пояснюють через } \\
\text { асоціативне } \\
\text { значення }\end{array}$ & $\begin{array}{c}\text { Семантично } \\
\text { аномальне } \\
\text { значення }\end{array}$ & $\begin{array}{c}\text { Не вступають } \\
\text { у комунікацію }\end{array}$ \\
\hline $\begin{array}{c}n \\
\mathrm{n}=378\end{array}$ & 4,2 & 35,2 & 57,4 & - & 3,2 \\
\hline
\end{tabular}

Про те, що в окремих дітей розвинена елементарна метафорична компетенція розуміння підтексту окремих прислів'їв свідчили їхні пояснення, в яких або давався повний опис прислів'я, тобто дитина пояснювала переносне значення, або давався неповний опис прислів'я, але наближений до правильного його трактування. Наприклад: 1. «Людина без друзів, що дерево без коріння» «Одинока людина» (Олександра П.), «Самотня» (Юля К.), «Це дерево без коріння, і людині скучно без друзів, як дереву без вєток» (Сергій Х.), «Це така, яка самотня людина» (Юля К.), «Треба, щзоб були друзі» (Костя Г.), «Це дуже пагано, тому що без друзів сумно» (Оксана Б.). 2. «Без труда нема плода» - «Без пращі нічого не росте» (Юля К.), «Треба трудитися» (Андрій О.), «Треба працюювати» (Олександра П.). 3. «Що посієш, те й пожнеш» «Якщо людина зробить гарну справу, після неї буде ще гарніше» (Юля К.). 4. «Хочеш їсти калачі - не сиди на печі» - «Робить треба» (Андрій О.), «Не можна бути ледачим» (Олександра П.), «Якщо хочеш їсти, то треба праџювати» (Юля К.), «Не можна лінуватися» (Костя Г.). 5. «Лежачого хліба ніде немає» - «Треба робити, лежачого хліба не буває» (Віка К.), «Якщо людина не буде працювати, в неї не буде хліба» (Юля К.). 6. «Куй залізо, поки воно ще гаряче» - «Поки ще можна щзось зробити» (Андрій В.), «Треба робити швидко» (Олександра П.).

Дітям, яким було важко пояснювати смисл прислів'їв (або які взагалі не виявляли спроб їх інтерпретувати), пропонувалися готові варіанти тлумачення для вибору, серед яких - перша відповідь була 
Peculiarities in Understanding of Indirect Meaning of Proverbs...

правильною (смисл прислів’я); друга - в прямому значенні; третя 3 випадковим асоціативним значенням, наприклад «Ласа кішка до риби, та у воду лізти не хоче» (1. Ледар тікає від роботи і йому завжди ніколи, а от їсти - завжди перший і час має. 2. Кішка дуже любить рибу, але у воду лізти не хоче. 3. Кішка любить ловити мишку). У такий спосіб полегшувалося завдання самостійного словесного оформлення думки при поясненні смислу прислів їв.

У цьому випадку співвідношення розуміння смислу прислів їв порівняно 3 першим показником (без запропонованих варіантів) кількісно змінювалося. Так, 16,4\% дітей обирали правильний варіант, 54,5\% дітей вибирали пряме значення прислів'я, 27,5\% респондентів здійснювали вибір асоціативного варіанту значень, 1,6\% дітей вибирали семантично аномальний зміст (див. табл. 2).

Таблиця 2. Вибір дошкільниками значень прислів”ї 3 поданих варіантів значень

\begin{tabular}{|c|c|c|c|c|}
\hline \multirow{2}{*}{$\begin{array}{l}\text { Кіл-ть } \\
\text { дітей }\end{array}$} & \multicolumn{4}{|c|}{ Варіанти значень прислів'їв } \\
\hline & $\begin{array}{c}\text { Розуміння глибинного } \\
\text { смислу }\end{array}$ & $\begin{array}{c}\text { Розуміння прямого } \\
\text { значення }\end{array}$ & $\begin{array}{c}\text { Асоціативне } \\
\text { значення }\end{array}$ & $\begin{array}{l}\text { Не вступають } \\
\text { у комунікацію }\end{array}$ \\
\hline $100 \%$ & 16,4 & 54,5 & $27,5 \%$ & 1,6 \\
\hline $\mathrm{n}=378$ & 62 & 206 & 104 & 6 \\
\hline
\end{tabular}

Як засвідчено табл. 2, у дітей наявна інтуїтивна мовна здатність відчувати загальний смисл прислів”їв. Проте їм важко правильно вербалізувати цей смисл при відсутності варіантів відповідей.

Найбільші труднощі (навіть у ситуації вибору варіантів тлумачень) в дітей викликали такі прислів'я: «Ласа кішка до риби, та у воду лізти не хоче», «Не плюй у криницю, бо згодиться води напитися», «Слово - не горобець, вилетить - не впіймаєш», «Лежачого хліба ніде немає», «Не все те золото, що блищить», «Куй залізо, поки воно ще гаряче». У тлумаченні цих прислів”їв діти припускалися помилок.

Неправильні тлумачення змісту прислів’їв було розподілено на такі групи:

I. Пояснення змісту прислів'їв через розкриття прямого значення, наприклад: 1. «Людина без друзів, що дерево без коріння» - «Людина не має друзів» (Сергій Х.). 2. «Хочеш їсти 
калачі - не сиди на печі» - «Це значить треба спочатку поїсти пиріжки, а потім вже лізти на піч, щооб кришки не накришити» (Даня Ч.), «Не треба сидіти на печі, треба їсти калачі на кріслі» (Настя М.), «Якщуо хочеш їсти калачі, треба злізти з печі» (Віка К.). 3. «Лежачого хліба немає» - «Хліб не можна класти на пол, от і говорять, щзо не буває» (Сергій Х.). 4. «Не все те золото, що блищить» - «Це золото, яке блищить» (Віка К.), «Блищуати може тільки золото» (Андрій Р.), «Все золото блищить» (Ілля М.).

До неправильних пояснень було віднесено й такі тлумачення, коли діти розкривали зміст прислів ёв у прямому значенні через уявну причину та наслідки, які можуть бути, наприклад: 1. «Ласа кішка до риби, та у воду лізти не хоче» - «Риба плаває, плаває, а кішка не лізе у воду, бо боїться води» (Сергій Х.), «Бо кішка боїться водички» (Юля К.), «Кішка любить рибку, не лізе у воду, тому щзо боїться води» (Олександра П.), «Кішка не хоче лізти у воду, бо тоді вона намокне» (Аліна Н.), «Кішка любить рибку та не лізе у воду, не хоче, бо тоді вона може потонути, бо не вміс плавати» (Артем В.). 2. «Хочеш їсти калачі - не сиди на печі» «Бо того, щзо можна обпектися» (Руслан О.).

II. Пояснення змісту прислів'я через асоціативні значення дошкільники здійснювали в такі способи:

а) орієнтувалися в прислів'ї на головне (ключове) слово при ігноруванні контексту (ознаку ключового слова-образу діти розшифровують через його характеристику), наприклад: 1. «Слово не горобець, вилетить - не впіймаєш» - «Ворона летить» (Ілля М.), «Горобець - ну це така пташка, вона бистро літає» (Ніна П.), «Горобець співає» (Еміль С.), «Слово не літає» (Маша П.), «Слово не можна впіймати, воно не літає» (Віка Н.), «Бо горобець швидко літає» (Віка С.). 2. «Куй залізо, поки воно ще гаряче» - «Залізо гаряче» (Поліна Г.).

б) наводили приклади 3 життя, наприклад: 1. «Що посієш, те й пожнеш» - «B саду ми з вихователькою посіяли квіти» (Поліна Г.). 2. «Хочеш їсти калачі - не сиди на печі» - «У моєї бабушки в селі $\epsilon$ nіч» (Рома Г.). 3. «Лежачого хліба ніде нема» - «Хліб у магазіні» (Еміль С.), « $C$, він у магазині лежить, я бачив як ми з мамою були в магазині» (Віталік В.);

в) трактували смисл прислів'я через формулювання мети, наприклад: 1. «Без труда нема плода» - «Треба пращювати, щуоб 
Peculiarities in Understanding of Indirect Meaning of Proverbs...

гроші заробляти» (Маринка Ш.). 2. «Що посієш, те й пожнеш» «Треба сіяти багато, щчоб було щзо їсти» (Андрій О.), «Треба багато садить, щзоб було щзо їсти» (Юля К.).

Отже, констатувальний експеримент засвідчив, що дошкільники не можуть загальмувати прямі о́брази або асоціації, які в них виникають, і перейти від прямих поверхових мовних значень слів до підтексту прислів'я, його глибинної суті.

Аналіз результатів обсервації здатності дітей розуміти смисл прислів”їв засвідчив наявність у них різних рівнів розвитку цієї здатності: достатній, середній, низький (див. табл. 3).

Таблиця 3. Рівні розвитку здатності розуміти глибинний смисл прислів'їв у дітей старшого дошкільного віку

\begin{tabular}{ccccc}
\hline К-сть дітей & Високий & Достатній & Середній & Низький \\
\hline$\%$ & - & 16,4 & 54,5 & 29,1 \\
$\mathrm{n}=378$ & - & 62 & 206 & 110 \\
\hline
\end{tabular}

Високий рівень розвиненості в респондентів здатності розуміти смисл прислів'їв не виявлено. Достатній рівень $(16,4 \%)$ розвиненості здатності розуміти прислів'я визначено за критерієм уміння дітей пояснювати переносне значення окремих прислів'їв або які здійснюють неповний опис прислів'я, але наближений до переносного значення. Водночас ці діти спроможні здійснити правильний вибір переносного значення прислів'їв 3 поданих варіантів значень. Середній рівень (54,5\%) встановлено 3 урахуванням здатності дітей розуміти прислів'я в прямому значенні, але неспромжності самостійно розшифрувати підтекстову інформацію прислів'я. У ситуації вибору варіанта значення прислів'я 3 поданих варіантів значень ці діти орієнтуються як на переносне значення окремих прислів”їв, так і на пряме. До низького рівня розвиненості здібності розуміти прислів'я було віднесено $29,1 \%$ дітей, які розкривали зміст тільки окремих прислів”їв через асоціативне значення. Навіть у ситуації вибору варіанта значення 3 поданих допоміжних прикладів, діти цього рівня сформованості навику або вибирають асоціативне значення, або не можуть взагалі здійснити вибір. До цього рівня віднесено й тих респондентів, які не намагаються вступити в комунікацію з експериментатором. 
Аналіз результатів виконання дітьми завдань на розуміння iдiом (розв'язати язик, кривити душею, знати на зубок, язик без кісток, водою не розлити, ловити гав, лічити ворон, бити байдики, дати спокій) засвідчив наступне: 7,4\% дітей пояснювали переносне значення ідіом; 35,4\% дітей пояснювали ідіоми в прямому значенні; 44,2\% респондентів пояснювали зміст ідіом через асоціативне значення; 9,8\% дошкільників давали семантично аномальні відповіді; 3,2\% дітей не вступали у комунікацію 3 експериментатором (див. табл. 4).

Таблиця 4. Стан розвитку здатності розуміти пряме й переносне значення ідіом у дітей 5-річного віку

\begin{tabular}{|c|c|c|c|c|c|}
\hline \multirow{2}{*}{$\begin{array}{c}\text { Кіл-сть } \\
\text { дітей }\end{array}$} & \multicolumn{4}{|c|}{$\begin{array}{c}\text { Стан розвитку здатності розуміти пряме } \\
\text { й переносне значення ідіом }\end{array}$} & \multirow{2}{*}{$\begin{array}{c}\text { Не } \\
\text { вступають у } \\
\text { комунікацію }\end{array}$} \\
\hline & $\begin{array}{c}\text { Пояснюють } \\
\text { переносне } \\
\text { значення }\end{array}$ & $\begin{array}{c}\text { Пояснюють } \\
\text { пряме } \\
\text { значення }\end{array}$ & $\begin{array}{c}\text { Пояснюють через } \\
\text { асоціативне } \\
\text { значення }\end{array}$ & $\begin{array}{c}\text { Семантично } \\
\text { аномальне } \\
\text { значення }\end{array}$ & \\
\hline$\%$ & 7,4 & 35,4 & 44,2 & 9,8 & 3,2 \\
\hline $\mathrm{n}=378$ & 28 & 134 & 167 & 37 & 12 \\
\hline
\end{tabular}

3 таблиці 4 видно, що 7,4\% дітей здатні пояснити переносне значення ідіом. Хоча діти давали неповний опис фразеологічних зрощень, проте він був наближений до правильного трактування. Наприклад: 1. «Розв’язати язик» - «Говорити» (Настя М.), «Це балакать» (Еміль Е.), «Заговорити» (Артур С.). 2. «Водою не розлити» - «Дружсні» (Назар Ч.). 3. «Знати на зубок» - «Букви розкласти і знати на зубок» (Каріна Д.). 4. «Ловити гав» - «Не слухати» (Руслан П.). 5. «Кривити душею» - «Це робить людина, яка обманює» (Вікторія І.).

Характерною особливістю пояснень дітей, що засвідчували їх здатність розуміти переносне значення, було розкриття смислу ідіоми за допомогою конкретних прикладів, які $\epsilon$ одним із безпосередніх проявів узагальненого переносного значення певного ідіоматичного виразу. Наприклад: «Дати спокій» - «Не кричати, якщз мамуся буде відпочивати», «Сслі мама говорить по телефону, треба мовчки сидіти тихенько» (Альона Д.), «Треба дати взрослим спокій, коли вони хочуть відпочити, то не потрібно їх перебивати» (Андрій В., Андрій М.). 
Peculiarities in Understanding of Indirect Meaning of Proverbs...

До правильних відповідей віднесено також такі, в яких зміст ідіоми доречно пов'язувався 3 життєдіяльністю дітей, наприклад: «Знати на зубок» - «Букви розкласти і знати на зубок» (Каріна Д.), «Віршика вивчити на свято і тоді знати на зубок» (Оленка К.).

Розуміння переносного значення ідіом дітьми, які затруднювалися пояснювати їх смисл, відбувалося швидше i без значних ускладнень, коли їм пропонувалися готові варіанти тлумачення. Так «знімалася» проблема самостійного словесного оформлення думки при поясненні переносного значення ідіом. Дітям пропонувалося для вибору кілька варіантів відповідей, серед яких перша відповідь була правильною (переносне значення); друга в прямому значенні; третя - асоціативна; четверта - семантично аномальна. Наприклад: «Лічити ворон» (1. Нічого не робити, ледарювати. 2. Порахувати ворон. 3. Ворони прилітають на город i клюють горох. 4. Ворона хвора і лікар ії лічить).

У цьому випадку співвідношення розуміння переносного значення ідіом порівняно з першим результатом (без запропонованих варіантів) кількісно змінювався. Так, 20,4\% дітей обирали правильний варіант, 59,5\% дітей вибирали пряме значення ідіоми, $14,8 \%$ дошкільників здійснювали вибір асоціативного варіанту значень, 4\% респондентів обирали варіант, що розкривав семантично аномальне значення; $1,3 \%$ дітей не вступали у комунікацію 3 експериментатором (див. табл. 5).

Таблиця 5. Вибір дошкільниками переносного значення ідіом 3 поданих варіантів значень

\begin{tabular}{|c|c|c|c|c|c|}
\hline \multirow{2}{*}{$\begin{array}{l}\text { Кіл-сть } \\
\text { дітей }\end{array}$} & \multicolumn{4}{|c|}{$\begin{array}{c}\text { Стан розвитку здатності розуміти пряме } \\
\text { і переносне значення ідіом }\end{array}$} & \multirow{2}{*}{$\begin{array}{c}\text { Не } \\
\text { вступають у } \\
\text { комунікацію }\end{array}$} \\
\hline & $\begin{array}{c}\text { Переносне } \\
\text { значення }\end{array}$ & $\begin{array}{c}\text { Пряме } \\
\text { значення }\end{array}$ & $\begin{array}{c}\text { Асоціативне } \\
\text { значення }\end{array}$ & $\begin{array}{c}\text { Семантично } \\
\text { аномальне } \\
\text { значення }\end{array}$ & \\
\hline$\%$ & 20,4 & 59,5 & 14,8 & 4 & 1,3 \\
\hline $\mathrm{n}=378$ & 77 & 225 & 56 & 15 & 5 \\
\hline
\end{tabular}

Отже, як видно 3 таблиці 5, у ситуації додаткового стимулювання частина дітей здатна вибрати 3 варіантів значень правильний варіант - переносне значення ідіом. 
Діти, в яких нерозвинена здатність розуміти переносне значення ідіом, давали пояснення, які було класифіковано на такі підгрупи.

I. Заміна переносного значення ідіоми прямим значенням:

а) через виведення ідіоматичного значення тільки із денотативних значень окремих слів, із яких воно складається. Наприклад: 1. «Водою не розлити» - «Нести акуратно, щзоб не розлити воду» (Настя М.), «Вода не розливається із чашки» (Віка Р.), «Воду не розіллєш» (Катя Д.), «Це означає, щуо багато води налить $і$ ï упустити, $і$ розлити» (Олександра К.). 2. «Язик без кісток» - «Я бачив мультік, де хлопчик сказав зайцю - язик без кісток» (Максим С.), «Коли я бачив мультик, то йожик сказав не те щзо треба, то йому сказали, щзо в нього язик без кісток» (Назар М.);

б) шляхом заміни ідіоми лексичним синонімом. Наприклад: «Водою не розлити» - «Не хлюпатися у воді» (Андрій А.); «Кріпкі» (Ілля Т.). Діти розуміли семантику правильно, хоча виражали неточно. При поясненні вони не спроможні перенести ці конкретні відносини на взаємини людей, дітей і зробити узагальнення, тому тлумачили їх безпосередньо;

в) через тавтологію з порушенням структури іносказання, на зразок: «Водою не розлити» - «Воду не розіллєш» (Катя М.); «Язик без кісток» - «Немає кісточок у язику» (Ліза Б.); «Гав ловити» «Ловлять гав люди» (Оксана Ж.); «Лічити ворон» - «Ворони лічать хтось» (Антон К.).

II. Тлумачення змісту ідіом через асоціативні значення:

а) шляхом заміни значення ідіом вільними словосполученнями, словами й реченнями 3 іншою семантичною наповненістю, наприклад: «Гав ловити» - «Бути неслухняним, бігати, а коли мама каже, не слухатися ї̈ (Настя Б.), «Можна попитать включити телевізор $і$ не сказати, будь ласка» (Свєта Т.), «Байдикувати» (Андрій В.), «Нічого не робити» (Іра П.), «Довго за комп'ютером сидіти, нічого не робити, не допомагати» (Андрій М.);

б) через орієнтацію на головне (ключове) слово в ідіомі, ігнорування контексту (ознаку ключового слова-образу діти розшифровують через його характеристику). Наприклад: 1. «Ловити гав» - «Собаку ловити» (Владік М.), «Собака гавкає» (Антон П.). 2. «Знати на зубок» - «Знати як зуби чистити» (Еміль С.). 
Peculiarities in Understanding of Indirect Meaning of Proverbs...

3. «Дати спокій» - «Спокійним бути» (Лєра Л.). 4. «Водою не розлити» - «Воду треба не розливати, а наливати» (Катя Б.);

в) через припущення: 1. «Знати на зубок» - «Це про зуби, як знати як їх чистити?» (Еміль С.). 2. «Лічити ворон»- «Це як ворони сидять на городі $і$ їх лічити?» (Еміль С.);

г) через причину i наслідки. Наприклад: 1. «Знати на зубок» - «Тому щзо треба все знати» (Поліна Г.), «Тому щзо треба писати гарно олівчиком» (Сашко Н.). 2. «Лічити ворон» - «Бо вони заболіли» (Артур С.);

г) через формулювання мети. Наприклад: 1. «Водою не розлити» - «Щоб напитися» (Оля В.), «Щоб принести воду мамі» (Оксана К.). 2. «Язик без кісток» - «Щоб язика впихнути в рот без кісток» (Андрій В.).

III. Семантично аномальні відповіді:

a) через використання прислівника, що виражає (позначає) ознаку міри, ступеня. Наприклад: 1. «Розв’язати язик» - «Нелегко» (Максим К.). 2. «Ловити гав» - «Важко» (Наталка Д.), «Бігом» (Вадим К.). 3. «Водити за ніс» - «Акуратно» (Андрій К.). 4. «Лічити ворон» - «Бистро». 5. «Бити байдики» - «Погано» (Антон К.), «Голосно» (Роман С.), «Сильно» (Антон П.);

б) через висловлювання, побудовані на спробах простого відгадування змісту ідіом, наприклад: 1. «Лічити ворон» - «Погане щзось сказати» (Ніка Б.), «Врач» (Настя Н.). 2. «Гав ловити» «Не слухатися маму» (Віта К.), «Звуки якісь» (Еміль С.), «Кидати щзось» (Віта Г.), «Прогулювати» (Назар Ч.), «Не робити ияього» (Костя Б.). 3. «Кривити душею» - «Ротом кривити» (Настя П.). 4. «Бити байдики» - «У барабани бити палками» (Костя Б.), «Бити палкою по дереву» (Антон П.). 5. «Дати спокій» - «Сnать на кроваті» (Маша Р.), «Успокоївся як поплакав» (Оксана Ж.). 6. «Розв’язати язик» - «Зав'язати мішок» (Антон П.), «Шнурок у кедах» (Міша Г.).

Аналіз висловлювань дітей дав змогу встановити низку труднощів, що виникали в дошкільників у процесі декодування переносного значення ідіом. Серед них такі:

- труднощі гальмування денотативних значень окремих слів, що входять в ідіоматичний вираз;

- труднощі гальмування сторонніх (випадкових) асоціацій, що спричиняють смислові інверсії. 
На основі аналізу отриманого емпіричного мовленнєвого матеріалу та виявлених труднощів декодування дітьми ідіом було встановлено причини виникнення цих труднощів, як-от:

- нерозвиненість здатності абстрагуватися від денотативного значення окремих слів, з яких утворюється ідіома;

- абстрактність ідіоматичного (переважаючи конотативного аспекту) значення слів-компонентів ідіом;

- обмежений життєвий досвід дітей;

- домінування в дітей наочно-чуттєвих вражень, життєвих ситуацій i конкретно-образного мислення над абстрактним i логічним мисленням;

- переважання у дітей синтагматичного об'єднання слів у мовленнєво-мисленнєвому акті при сприйманні ідіоми і тлумачення іiі значення;

- недостатня періодичність сприймання та вживання дітьми ідіом у власному мовленні.

Аналіз результатів обсервації здатності дітей розуміти переносне значення ідіом засвідчив наявність нерівномірності розвитку в дітей цієї здатності, зокрема таких рівнів: високий, достатній, середній, низький (див. табл. 6).

Таблиця 6. Рівні розвитку здатності розуміти переносне значення ідіом у дітей 5-річного віку

\begin{tabular}{ccccc}
\hline Кіл-сть дітей & Високий & Достатній & Середній & Низький \\
\hline$\%$ & 7,4 & 36 & 43,6 & 13 \\
$\mathrm{n}=378$ & 28 & 136 & 165 & 49 \\
\hline
\end{tabular}

Високий рівень розвиненості здатності розуміння переносного значення ідіом виявлено у 7,4\% дітей. Вони не тільки розуміють ідіоматичне значення, але й намагаються його пояснювати, але у своєрідний спосіб, притаманний дітям цього віку (пояснюють ідіоматичне значення шляхом розкриття ідіом за допомогою конкретних прикладів, що $\epsilon$ одним 3 безпосередніх проявів узагальненого переносного значення певної ідіоми; дають опис ідіоми, який наближений до правильного трактування; замінюють ідіоми синонімічним словосполученням; доречно пов'язують зміст ідіоми з життєдіяльністю дітей). До достатнього рівня розвиненості 
Peculiarities in Understanding of Indirect Meaning of Proverbs...

здатності розуміти ідіоми було віднесено 36\% дітей, які розуміють ідіоми в прямому значенні, а також розкривають переносне значення фразем не шляхом самостійного тлумачення, а лише в спосіб вибору варіанта значення з поданих їм на допомогу функціональних еквівалентів. До середнього - було віднесено 43,6\% дітей, які не розуміють переносне значення ідіом, проте в ситуації додаткового стимулювання (вибору варіанта значення із запропонованих) вибирають як переносне значення, так і асоціативне. До низького рівня було віднесено 13\% дітей, які не розуміють ні переносного, ні прямого значення ідіом. У ситуації додаткового стимулювання діти вибирають як асоціативне значення, так і семантично аномальне. До цієї групи віднесено також респондентів, які не вступали в комунікацію з експериментатором.

Експериментальне дослідження дало змогу здійснити порівняння, як дошкільники розуміють переносне значення прислів ’їв та ідіом (див. табл. 7).

Таблиця 7. Порівняльна таблиця розвитку здатності розуміти переносне значення прислів 'їв та ідіом у дітей 5-річного віку

\begin{tabular}{|c|c|c|c|c|c|}
\hline $\begin{array}{c}\text { Кіл-сть } \\
\text { дітей }\end{array}$ & $\begin{array}{c}\text { Пояснюють } \\
\text { переносне } \\
\text { значення }\end{array}$ & $\begin{array}{c}\text { Пояснюють } \\
\text { пряме } \\
\text { значення }\end{array}$ & $\begin{array}{c}\text { Пояснюють } \\
\text { через } \\
\text { асоціативне } \\
\text { значення }\end{array}$ & $\begin{array}{c}\text { Семантично } \\
\text { аномальне } \\
\text { значення }\end{array}$ & $\begin{array}{c}\text { Не } \\
\text { вступають у } \\
\text { комунікацію }\end{array}$ \\
\hline \multicolumn{6}{|c|}{ Розуміння прислів'їв } \\
\hline$\%$ & 4,2 & 35,2 & 57,4 & - & 3,2 \\
\hline $\mathrm{n}=378$ & 16 & 133 & 217 & - & 12 \\
\hline \multicolumn{6}{|c|}{ Розуміння ідіом } \\
\hline$\%$ & 7,4 & 35,4 & 44,2 & 9,8 & 3,2 \\
\hline $\mathrm{n}=378$ & 28 & 134 & 167 & 37 & 12 \\
\hline
\end{tabular}

Отже, як видно 3 табл. 7, діти 5-річного віку краще розуміють переносне значення ідіом, ніж прислів'їв. Дошкільники розкривають семантично аномальне значення тільки ідіом. Семантично аномальних відповідей у ситуації тлумачення смислу прислів'їв дітьми не виявлено.

\section{Дискусії}

Отримані в констатувальному експерименті результати 3 дітьми 5-річного віку, які відвідували заклади дошкільної освіти, 
дають змогу здійснити порівняння 3 подібними дослідженнями, виконаними на матеріалі італійської, французької, англійської, норвезької, китайської, російської мов, і провести деякі аналогії й висловити певні дискусійні міркування.

По-перше, підтверджуємо правильність гіпотези про те, що частотність впливу ідіом на сприйняття дітей сприяє розуміння ними переносного значення цих метафоричних виразів (Levorato \& Cacciari, 1992). Дидактично насичене ідіомами й прислів'ями мовленнєве середовище «3 високим розвивальним потенціалом» (Федоренко, Фомичева, Лотарев \& Николеичева, 1984), в якому навчалися діти (без цілеспрямованої роботи 3 розшифрування їх смислу), створювало передумови й умови для прояву в окремих дітей ідіоматичної й образної компетенції.

По-друге, гіпотеза про те, що контекст суттєво впливає на розуміння дітьми значення ідіом (Gibbs, 1987; Caillies \& Le SournBissaoui, 2006; Cain, Towse \& Knight, 2009; Hsieh \& Hsu, 2010), підтверджується повсякденною практикою роботи 3378 дітьми дошкільного віку, які брали участь в експерименті. Переносне значення прислів'їв та ідіом всі вони розуміли завдяки саме контексту - тих оповідань і казок, які їм читали дорослі та в яких містилися ці вирази. Саме контекст сприяв вниканню дітей у глибинний метафоричний смисл ідіом, а також афористичнообразний смисл прислів’їв.

По-третє, повністю підтверджуємо гіпотезу (Winner, Rosenstiel \& Gardner, 1976; Vosniadou \& Ortony, 1983; Eliseeva, Gutsc \& Marini, 2017; Елисеева \& Горобец, 2017), згідно 3 якою надана можливість вибирати значення ідіоматичного виразу із запропонованих варіантів значень підвищує розуміння ними ідіом. 18,4\% дітей з 378 дошкільників, які взяли участь у нашому експерименті, виявляють фігуральну компетенцію без ніякої попередньої дидактичної готовності.

По-четверте, не погоджуємося 3 гіпотезою (Honeck, Sowry \& Voegtle, 1978), згідно 3 якою для виявлення здатності дітей декодувати смисл прислів'їв недійсною $є$ процедура використання завдань на усне інтерпретування дітьми їх змісту. Нашим експериментом підтверджено, що хоча й незначна частина 5-річних дітей, але все-таки вона спроможна (різною мірою, залежно від розвиненості мовленнєвої компетентності) правильно 
Peculiarities in Understanding of Indirect Meaning of Proverbs...

тлумачити переносне значення вперше сприйнятих прислів“̈̈в та ідіом. Отримані нами в експерименті дані підтверджують гіпотезу (Vosniadou \& Ortony, 1986), відповідно до якої використання в експериментальній роботі 3 дітьми завдань на тлумачення ідіом i методів, які передбачають пояснення їх переносного значення через парафраз спричинює недооцінку метафоричної компетенції дітей дошкільного віку.

\section{Висновки}

Діти 5-річного віку здатні розуміти переносне значення ідіом, виявляють метафоричну компетенцію або через тлумачення смислу ідіоми, або через вибір серед поданих їм варіантів значень саме ідіоматичного значення, абстрагуючись від прямого значення слів, що входять до ідіоматичного виразу. При інтерпретації смислу деяких ідіом дошкільники вдаються до таких стратегій: у релевантному ідіоматичному значенню парафрази пояснюють глибинний смисл ідіоми; тлумачать зміст ідіоми через синонімічне словосполучення; розкривають абстрактний смисл ідіом шляхом співвіднесення загального (смислу ідіоми) i часткового (конкретного прояву змісту ідіоми в реальній діiі) в їх єдності. Виокремлюють у змісті ідіоми аспекти, доречно пов'язані 3 поведінкою й життєдіяльністю дітей. Проте ці діти, виявляючи певні рівні розуміння, ще не здатні до широких узагальнень, яскраво вираженого вербальнологічного мислення.

Розуміння прислів”їв у дітей цього віку наштовхується на складність сприйняття художнього образу й смислової двоплановості, закладених у них . Виділити концепт прислів'я, перейти до його внутрішнього смислу та підтексту здатна незначна частина дітей. Стратегія, за якою діти виявляють розуміння прислів“їв, йдучи від зовнішньої форми й конкретики до глибинної суті, полягає лише в процедурі вибору метафоричного алегорично-образного значення прислів “їв серед інших варіантів значень (метафоричних, денотативних, асоціативних, аномально-смислових). Дошкільникам значно важче зрозуміти смисл прислів’”̈в, у змісті яких відтворено образи тварин, предметів («Ласа кішка до риби, а у воду лізти не хоче», «Слово - не горобець, вилетить - не впіймаєш», «Куй залізо поки воно ще гаряче» та ін.), ніж прислів’я, в яких відтворена побутова (життєва) ситуація («Без труда нема плода», «Хочеш 
їсти калачі - не сиди на печі», «Що посієш, те й пожнеш» та ін.). За алегоричними художніми образами тварин i властивостями предметів діти не можуть зрозуміти усталеного кодифікованого значення, що закріплено фразеологічними та іншими словниками.

У старшому дошкільному віці закладаються передумови лінгвістично коректного розуміння ідіом і прислів 'їв, яке виявляється на більш пізніх етапах мовленнєво-мисленнєвого онтогенезу.

У процесі порівняння розвитку здатності в дітей розуміти переносне значення прислів”їв та ідіом було встановлено, що складнішими для розуміння дітьми виявилися прислів'я, ніж ідіоми. Це пояснюється тим, що ідіоматичні вирази становлять собою єдине поняття й образну номінацію, яку дитина часто сприймає в побуті від дорослих у конкретній ситуації життєдіяльності. Тому вона швидше включає почуте словосполучення в новий ланцюг асоціацій, абстрагуючись від прямого значення слів ідіом. Щодо прислів'їв, то цей народний афористичний образний вислів постає перед дитиною як більш складне когнітивне завдання, яке передбачає розшифрування узагальненої думки або висновку, вникання в смисл дидактично зорієнтованих фразеологічних виразів. Саме тому вони й викликають у дітей більше труднощів у тлумаченні смислу цього короткого влучного оригінального вислову. Якщо діти здатні експлікувати смисл ідіом, засвідчуючи розуміння, то розуміння смислу прислів'їв діти виявляють лише в спосіб вибору переносного значення прислів'їв із поданих варіантів значень.

\section{References}

Ackerman, B.P. (1982). On comprehending idioms: Do children get the picture? Journal of Experimental Child Psychology, 33(3), 439-454. doi.org/10.1016/00220965(82) $90058-3$

Ackerman, B.P. (1983). Form and function in children's understanding of ironic utterances. Journal of Experimental Child Psychology, 35(3), 487-508. doi. org/10.1016/0022-0965(83)90023-1

Artemyeva, T.V. (2013). Peculiarities of Primary School Children Figurative Speech Comprehension. World Applied Sciences Journal, 27(6), 738-741. doi: 10.5829/ idosi.wasj.2013.27.06.13709

Artemyeva, T.V., \& Nurieva, A.S. (2007). Razvitie ponyatiynogo myshleniya detey $\mathrm{s}$ narusheniyami rechi posredstvom megafor $\mathrm{i}$ poslovits [The development of conceptual thinking of children with speech disorders through metaphors and proverbs]. Aktualnye problemy spetsialnoy psikhologii $i$ korrektsionnoy pedagogiki - Actual problems of special psychology and corrective pedagogics. A.I. Akhmetzyanovoy (Ed.). Kazan: Otechestvo [in Russian]. 
Peculiarities in Understanding of Indirect Meaning of Proverbs...

Baskakova, I.L., \& Gluhov, V.P. (2008). Praktikum po psiholingvistike [Practical course on psycholinguistics]. Moscow: AST: Astrel [in Russian].

Beresneva, L.I., Dubrovskaya, L.A., \& Ovchinnikova I.G. (1995). Assotsiatsii detey ot 6 do 10 let [Children's associations from 6 to 10 years]. Perm [in Russian].

Cacciari, C., \& Levorato, M.C. (1989). How children understand idioms in discourse. Journal of Child Language, 16, 387-405. doi.org/10.1017/S0305000900010473

Caillies, S., \& Le Sourn-Bissaoui, S. (2006). Idiom comprehension in French children: A cock-and-bull story. European Journal of Developmental Psychology, 3(2), 189-206. doi.org/10.1080/17405620500412325

Caillies, S., \& Le Sourn-Bissaoui, S. (2013). Nondecomposable Idiom Understanding in Children: Recursive Theory of Mind and Working Memory. Canadian Journal of Experimental Psychology - Revue Canadienne de Psychologie Experimentale, 67(2), 108-116. doi: 10.1037/a0028606

Cain, K., Towse, A.S., \& Knight, R.S. (2009). The development of idiom comprehension: an investigation of semantic and contextual processing skills. Journal of Experimental Child Psychology, 102(3), 280-298. doi: 10.1016/j. jecp.2008.08.001

Chiappe, D.L., \& Chiappe, P. (2007). The role of working memory in metaphor production and comprehension. Journal of Memory and Language, 56(2), 172 188. doi.org/10.1016/j.jml.2006.11.006

Chukovskiy, K.I. (1960). Ot dvukh do pyati [From two till five]. Moscow [in Russian].

Detinina, O.B. (1987). Ustoychivye slovosochetaniya v detskoy rechi [Constant word formations in children's speech]. Detskaya rech kak predmet lingvisticheskogo izucheniya - Children's speech as a subject of linguistic study. Leningrad [in Russian].

Dyachenko, O.M. (1996). Razvitie voobrazheniya doshkolnikov [Preschool children imagination development]. Moscow: MO i PK, PI RAO [in Russian].

Eliseeva, N., \& Gorobets, E. (2017). Vospriyatie idiom russkogovoryashchimi detmi: materialy dlya neyrolingvisticheskogo oprisnika [Perception of idioms by Russian-speaking children: materials for a neurolinguistic questionnaire]. Filologiya i kultura - Philology and Culture, 4(50), 16-21 [in Russian].

Eliseeva, N., Guts, E.N., \& Marin, A. (2017). Comprehension of idiomatic expressions by Russian speaking typically developing children. Psychology in Russia: State of the Art, 10(4), 22-32. doi: 10.11621/pir.2017.0403

Elkonin, D.B. (1964). Razvitie rechi [Speech development]. Psikhologiya detey doshkolnogo vozrasta - Psychology of pre-school age children (pp. 115-182). Moscow [in Russian].

Ezell, H., \& Goldstein, H. (1991). Comparison of idiom comprehension of normal children and children with mental retardation. Journal of Speech and Hearing Research, 34, 812-819.

Fedorenko, L.P., Fomicheva, G.A., Lotarev, V.K., \& Nikolaicheva, A.P. (1984). Metodika razvitiya rechi detey doshkolnogo vozrasta [Methods of development of children's speech of preschool age] (2 $2^{\text {nd }}$ ed.). Moscow: Prosveshchenie [in Russian].

Ganych, D.I., \& Olijnyk, I.S. (1985). Slovnyk lingvistychnyx terminiv [Glossary of Linguistics Terms]. Kyiv : Vyshha shkola [in Ukrainian].

Gibbs, R. (1987). Linguistic factors in children's understanding of idioms. Journal of Child Language, 14(3), 569-586. doi: 10.1017/S0305000900010291

Gibbs, R.W. (1995). What proverb understanding reveals about how people think. Psychological Bulletin, 118, 133-154. 
Gromyak, R.T., Kovaliv, Yu.I., \& Teremko, V.I. (2007). Literaturnoznavchyj slovnykdovidnyk [Dictionary of literature science]. Kyiv: Akademiya [in Ukrainian].

Gvozdev, A.N. (1961). Voprosy izucheniya detskoy rechi [Questions of Children's Speech Study]. Moscow: Izd-vo APN RSFSR [in Russian].

Honeck, R., Sowry, B., \& Voegtle, K. (1978). Proverbial Understanding in a Pictorial Context. Child Development, 49(2), 327-331. doi.org/10.2307/1128694

Honeck, R., Sowry, B., \& Voegtle, K. (1976). Young Children's Understanding of Relationship Between Pictures and Proverbs. Bulletin of the Psychonomic Society, 8(4).

Hsieh, S., \& Hsu, J. (2010). Idiom Comprehension in Mandarin-Speaking Children. Psycholinguist Res, 39, 505. doi.org/10.1007/s10936-009-9145-Z

Ilyenkov, E.V. (1968). O voobrazhenii [About imagination]. Narodnoe obrazovanie Folk education, 3, 24-28 [in Russian].

Kalmykova, L., \& Mysan, I. (2014). Psyxolingvistychni aspekty frazeologiyi yak teoretyko-metodologichni zasady zbagachennya movlennya ditej ekspresyvnostylisty'chnymy zasobamy movy [Psycholinguistic Aspects of Phraseology as Theoretical and Methodological Foundations of Children's Speech Enriching]. East European Journal of Psycholinguistics, 1, 66-74 [in Ukrainian].

Kemper, S. (1981). Comprehension and the interpretation of proverbs. Journal of Psycholinguistic Research, 10, 179-198. doi.org/10.1007/BF01068037

Kharchenko, V.K. (1987). Semantika slova v detskoy rechi: problemy i nablyudeniya [Semantics of the word in children's speech: problems and observations]. Detskaya rech kak predmet lingvisticheskogo izucheniya - Children's speech as a subject of linguistic study [in Russian].

Le Sourn-Bissaoui, S., Caillies, S., Bernard, S., et al. (2012). Children's understanding of ambiguous idioms and conversational perspective-taking. Journal of Experimental Child Psychology, 112(4), 437-451. doi.org/10.1016/j. jecp.2012.02.003

Levorato, M.C, \& Cacciari, C. (1992). Childrens comprehension and production of idioms - the role of context and familiarity. Journal of Child Language, 19(2), 415-433. doi.org/10.1017/S0305000900011478

Lodge, D., \& Leach, E. (1975). Children's acquisition of idioms in the English language. Journal of Speech and Hearing Research, 18, 521-529. doi: 10.1044/ jshr.1803.521

Luriya, A.R. (1998). Yazyk i soznanie [Language and Cognition]. E.D. Khomskoy (Ed.). Rostov n/D: Feniks [in Russian].

Lyublinskaya, A.A. (1971). Detskaya psikhologiya [Children's psychology]. Moscow: Prosveshchenie [in Russian].

Miroshnichenko, O.F. (1986). Osobennosti detskoy rechi [Children's speech peculiarities]. Moscow [in Russian].

Mitkina, I.N. (2001). Osobennosti ovladeniya frazeologizmami detmi sedmogo goda zhizni [Features of mastering phraseologisms by children of the seventh year of life]. Candidate's thesis. Moscow [in Russian].

Mysan, I. (2017). Teoretiko-metodologichni zasadi studiyuvannya rozuminnya i vzhivannya ditmi starshogo doshkilnogo viku frazeologizmiv $\mathrm{v}$ movlenni [Theoretical and methodological bases of studying comprehension and use by children of senior preschool age phraseological units in speech]. Psiholingvistyka - Psycholinguistics, 22(1), 142-162. doi: https://doi.org/10.5281/ zenodo.1087970 [in Ukrainian]. 
Peculiarities in Understanding of Indirect Meaning of Proverbs...

Mysan, I.V. (2015). Zbagachennya movlennya ditej starshogo doshkilnogo viku frazeologizmamy [Enrichment of preschool children's speech by means of phraseology]. Candidate's thesis. Odesa [in Ukrainian].

Mysan, I. (2018). Psyxolingvistychni osoblyvosti rozvytku audiyuvannya frazeologizmiv u ditej starshogo doshkilnogo viku [Psycholinguistic Peculiarities of Phraseological Units Listening Development by Older Pre-school Age Children]. Psiholingvistyka - Psycholinguistics, 23(1), 219-241. doi.org/10.5281/ zenodo.1217900 [in Ukrainian].

Nechvolod, L.I. (2008). Suchasnyj slovnyk inshomovnyx sliv [Modern Dictionary of Foreign Words]. Xarkiv: TORSING PLYuS [in Ukrainian].

Nippold, M.A., Allen, M.M., \& Kirsch, D.I. (2000). How adolescents comprehend unfamiliar proverbs: The role of top-down and bottom-up processes. Journal of Speech Language and Hearing Research, 43(3), 621-630. doi.org/10.1044/ jslhr.4303.621

Nippold, M.A., Moran, C., \& Schwarz, I.E. (2001). Proverb comprehension in New Zealand and American youth: a cross-cultural comparison. New Zealand Journal of Speech-Language Therapy, 14-21.

Nippold, M.A., Leonard, L.B., \& Kail, R. (1984). Syntactic and conceptual factors in children's understanding of metaphors. Journal of Speech and Hearing Research, 27, 197-205.

Pearson, B.Z. (1990). The comprehension of metaphor by preschool children. Journal of Child Language, 17, 185-203.

Prinz, P. (1983). The development of idiomatic meaning in children. Language and Speech, 26, 263-272. doi.org/10.1177/002383098302600307

Prokhorov, A.M. (2004). Bolshoy entsiklopedicheskiy slovar [Big Encyclopedic Dictionary] ( $2^{\text {nd }}$ ed., rev.). Moscow: Norint [in Russian].

Rubinshteyn, S.L. (2001). Osnovy obshchey psikhologii [Basics of common psychology]. Moscow [in Russian].

Rubio-Fernández, P., \& Grassmann, S. (2016). Metaphors as Second Labels: Difficult for Preschool Children? Journal Psycholinguist Research, 45, 931-944. doi. org/10.1007/s10936-015-9386-y

Shynkaruk, V.I. (Eds.) (2002). Filosofskyj encyklopedychnyj slovnyk [Encyclopedic philosophic dictionary]. Kyiv: Abrys [in Ukrainian].

Synycya, I.O. (1974). Psyxologiya usnogo movlennya uchniv 4-8 klasiv [Psychology of verbal communication of pupils of the 4-8 grades]. Kyiv: Radyanska shkola [in Ukrainian].

Uekermann, J., Thoma, P., \& Daum, I. (2008). Proverb interpretation changes in aging. Brain and Cognition, 67(1), 51-57. doi.org/10.1016/j.bandc.2007.11.003

Ushinskiy, K.D. Rodnoe slovo [Native word]. Sobranie sochineniy - Collection of works (Vols. 6). Moscow-Leningrad: Akademiya pedagogicheskih nauk [in Russian].

Uzhchenko, V.D., \& Uzhchenko, D.V. (2007). Frazeologiya suchasnoyi ukrayinskoyi movy [Phraseology of the modern Ukrainian language]. Kyiv: Znannya [in Ukrainian].

Vosniadou, S., \& Ortony, A. (1983). The emergence of the literal-metaphoricalanomalous distinction in young children. Child Development, 54, 154-161. doi. org/10.2307/1129872

Vosniadou, S., \& Ortony, A. (1986). Testing the metaphoric competence of the young child: Paraphrase vs. enactment. Hum. Devel, 29, 226-230. 
Vosniadou, S., Ortony, A., Reynolds, R., \& Wilson, P. (1984). Sources of Difficulty in the Young Child's Understanding of Metaphorical Language. Child Development, 55(4), 1588. doi: 10.2307/1130028

Vygotskiy, L.S. (1999). Myshlenie $i$ rech [Thought and Language]. Moscow [in Russian].

Vygotskiy, L.S. (2000). Psikhologiya [Psychology]. Moscow: Izd-vo EKSMO-Press [in Russian].

Winner, E. (1988). The point of words: Children's understanding of metaphor and irony. Cambridge: Harvard University Press.

Winner, E., Rosenstiel, A., \& Gardner, H. (1976). The Development of Metaphoric Understanding. Development Psychology, 12, 289-297. doi.org/10.1037/00121649.12.4.289

Yoon, H, Schwarz, I., \& Nippold, M. (2016). Comparing proverb comprehension in Korean and American youth. Speech Language and Hearing, 19(3), 161-170. doi.org/10.1080/2050571X.2016.1164938

\section{АНОТАЦІЯ}

У дослідженні вивчалися психолінгвістичні особливості розуміння переносного значення прислів'їв та ідіом україномовних дошкільників. Експеримент проходив на базі закладів дошкільної освіти України. У ньому приймали участь 378 дітей у віці 5 до 5.5 років.

Для отримання даних про стан розвиненості компетенції розуміти переносне значення слів було використано психолінгвістичні методи: а) "оцінка розуміння смислу переносного значення метафор» (Выготский, 2000); б) "оцінка розуміння смислу прислів'їв" (Лурия, 1998). Застосовано психолінгвістичні методики: а) «Розуміння прислів"їв» (Лурия, 1998), адаптованої й для діагностування розуміння метафоричного значення ідіом дітьми; б) "Вибір одного тлумачення із поданих варіантів значень» (Баскакова \& Глухов, 2008; Eliseeva, Gutsc \& Marini, 2017); в) «Вибір одного варіанта значення з кількох парафраз ("Metod of select one of several possible paraphrases») (Winner, Rosenstiel \& Gardner, 1976; Vosniadou \& Ortony, 1983). Дітям було запропоновано висловитися про те, як вони розуміють подані їм для сприймання прислів'ї та ідіоми. Якщо у них виникали труднощі в експлікації смислів, то їм пропонували для вибору кілька варіантів тлумачень прислів'їв та ідіом, серед яких перших був правильним (у переносному значенні), другий - в прямому значенні, третій - 3 випадковим асочіативним значенням.

Експеримент засвідчив такі результати: у дітей наявна інтуїтивна мовна здатність відчувати загальний смисл прислів'їв та ідіом. Частина дітей 5-річного віку спроможна шляхом парафразу правильно вербалізувати переносне значення прислів'їв (4,2\%) та ідіом (7,4\%). У ситуації вибору одного варіанта значення з кількох парафраз 16,4\% diтей вибирають правильний варіант смислу прислів'я, 20,4\% 
Peculiarities in Understanding of Indirect Meaning of Proverbs...

дітей вибирають правильний варіант значення ідіоми. Складнішими для розуміння дітей виявилися прислів'я, ніж ідіоми. Це пояснюється тим, що ідіоматичні вирази становлять собою єдине поняття й образну номінацію, яку дитина часто сприймає в побуті від дорослих у конкретній життєвій ситуації. Тому вона швидше включає почуте словосполучення в новий ланцюг асочіацій, абстрагуючись від прямого значення слів ідіом. Розуміння прислів'я постає перед дитиною як більш складне когнітивне завдання, яке передбачає розшифрування узагальненої думки або висновку, вникнення в його смисл (підтекст). Саме тому прислів'я викликають у дітей більше труднощів в тлумаченні смислу, ніж ідіоми.

Ключові слова: переносне значення слів, прислів'я, ідіоми, сприймання, розуміння, діти дошкільного віку.

Калмыкова Лариса, Харченко Наталия, Мысан Инна. Особенности понимания детьми дошкольного возраста переносного значения пословиц и идиом

\section{АННОТАЦИЯ}

В исследовании изучались психолингвистические особенности понимания переносного значения пословиц и идиом украиноязычными дошкольниками. Эксперимент проходил на базе учреждений дошкольного образования Украины. В нем принимали участие 378 детей в возрасте от 5 до 5.5 лет.

Для получения данных о состоянии развития компетенции понимать переносное значение слов использованы психолингвистические методы: а) "оценка понимания переносного значения метафор" (Выготский, 2000); б) “оценка понимания смысла пословиц» (Лурия, 1998). Применены психолингвистические методики: а) «Понимание пословиц" (Лурия, 1998), адаптированная и для диагностики понимания метафорического значения идиом детьми; б) «Выбор одного толкования из представленных вариантов значений» (Баскакова \& Глухов, 2008; Eliseeva, Gutsc \& Marini, 2017) в) «Выбор одного варианта значения из нескольких парафраз ("Metod of select one of several possible paraphrases») (Winner, Rosenstiel \& Gardner, 1976; Vosniadou \& Ortony, 1983). Детям необходимо было высказаться о том, как они понимают представленные им для восприятия пословицы и идиомы. Если у них возникали трудности в экспликации смыслов, то им предлагались для выбора несколько вариантов толкований послович и идиом, среди которых первый вариант был правильным (переносное значение), второй - прямое значение, третий - случайное ассоциативное значение. 
Эксперимент дал возможность получить следующие результаты: у детей развита интуитивная языковая способность чувствовать общий смысл пословии и идиом. Часть детей 5-летнего возраста способна путем парафраз правильно вербализировать смысл послович $(4,2 \%)$ и переносное значение идиом (7,4\%). В ситуации выбора одного варианта значения из нескольких парафраз 16,4\% детей выбирают правильный вариант смысла пословии, 20,4\% детей выбирают правильный вариант переносного значения идиом. Сложнее для понимания детей оказались пословицы, чем идиомы. Это объясняется тем, что идиоматические выражения представляют собой единое понятие и образную номинацию, которую ребенок часто воспринимает в быту, слышит от взрослых в конкретной жизненной ситуации. Поэтому ребёнок скорее включает услышанное словосочетание в новую чепь ассочиаций, абстрагируясь от прямого значения слов идиом. Понимание пословиц является для ребенка более сложным когнитивным заданием, которое предусматривает расшифровку обобщенной мысли или умозаключения, необходимость вникать в её смысл (подтекст). Именно поэтому пословицы вызывают у детей больще трудностей в толковании смысла, чем идиомы.

Ключевые слова: переносное значение слов, пословицы, идиомы, восприятие, понимание, дети дошкольного возраста. 